\title{
INTERAKSI BUDAYA ETIS DAN KECERDASAN SPIRITUAL PADA HUBUNGAN MUATAN ETIKA DAN PERILAKU ETIS MAHASISWA (Survey pada Pendidikan Vokasi Akuntansi di Yogyakarta)
}

\author{
Rahmawati Hanny Y \\ Akademi Akuntansi YKPN Yogyakarta \\ rahmahanny@gmail.com
}

\begin{abstract}
This study aims to analyze the interaction of ethical culture, spiritual intelligence, ethical content, and students' ethical behavior. The population in this study is a student at one of the leading accounting vocational education institutions in Yogyakarta. Sampling technique in this research use purposive sampling. The number of samples in this study was 368 respondents. Data analysis using Moderated Regression Analysis (MRA). The results of this study indicate that the content of ethics affect the student's ethical behavior. The interaction of ethical culture on the relationship between ethical content and ethical behavior suggests it can strengthen its influence. Similarly, the interplay of spiritual intelligence that demonstrates can strengthen the relationship between ethical content and student ethical behavior.
\end{abstract}

Keywords: ethical content, ethical culture, spiritual intelligence, and ethical behavior

\section{PENDAHULUAN}

Kasus etika yang melibatkan kantor akuntan publik besar seperti Arthur Anderson dan kasus-kasus lainnya yang sejenis menyebabkan profesi akuntansi mengalami krisis kepercayaan. Kasus-kasus tersebut mengindikasikan bahwa profesi mengalami degradasi moral akibat praktik pelanggaran moral yang mereka lakukan. Finn, Munter, dan McCaslin menjelaskan bahwa akuntan publik memiliki kesempatan untuk melakukan tindakan tidak etis (Lucyanda dan Endro, 2012). Oleh karena itu, di mata masyarakat pemakai jasa profesi akuntan sangat dipengaruhi oleh perilaku etisnya.

Reiss dan Mitra (1998) mengungkapkan bahwa perilaku dari para pemimpin di masa depan dapat dilihat dari perilaku mahasiswa sekarang (Lucyanda dan Endro, 2012). Demikian halnya dengan perilaku etis praktisi akuntan masa depan, juga dapat dilihat dan dipelajari dari perilaku mahasiswa akuntansi saat ini. Perilaku mahasiswa menarik untuk diteliti karena disinyalir mempengaruhi perilaku etis mereka di masa yang akan datang. Oleh karenanya, problematika etika menjadi suatu isu yang penting dalam bidang akuntansi khususnya di perguruan tinggi, karena lingkungan pendidikan memiliki andil dalam menciptakan sumber daya manusia yang cerdas, trampil, dan bermoral, serta profesional. Perguruan tinggi sebagai penghasil sumber daya manusia yang professional diharapkan mampu memenuhi kebutuhan pasar, sehingga dituntut dapat menghasilkan tenaga professional yang kualifikasi keahlian sesuai bidang ilmunya, dan juga memiliki perilaku etis yang tinggi (Hastuti, 2007). Namun realitanya, pendidikan akuntansi strata satu pada umumnya hanya mengajarkan etika profesi akuntan pada mata kuliah pengauditan saja, padahal isu etika tidak hanya terkait dengan mata kuliah tersebut (Sapariyah et al. 2016). Dengan demikian, pendidikan tinggi akuntansi belum optimal melakukan penanaman nilai-nilai etis dalam proses pendidikan yang dilakukannya. Malone (2006) meneliti mengenai perilaku etis mahasiswa akuntansi dalam suatu lingkungan yang sudah familiar bagi mereka dan hasilnya menunjukkan bahwa jika situasi yang membahayakan datang, maka merekat tidak akan menyerah untuk berperilaku tidak etis. Selain itu, Malone (2006) juga menjelaskan perilaku etis mahasiswa saat ini akan berlanjut ke masa yang akan datang ketika mereka bekerja. Hal tersebut menunjukkan bahwa penanaman nilai etis dalam pendidikan harus dilakukan 
karena akan memberikan pengaruh pada perilaku mahasiswa di masa datang dalam berprofesi.

Penelitian-penelitian terdahulu terkait dengan sikap atau perilaku etis akuntan dan mahasiswa sudah banyak dilakukan, diantaranya yang dilakukan oleh Maryani dan Ludigdo (2001), Rahman (2003), Nugrahaningsih (2005), Ustadi dan Utami (2005), Tikollah, Triyuwono dan Ludigdo (2006); dan Fatmawati (2007); Becker dan Ulstad (2007), Triani (2011), Sari (2012), Lucyanda dan Endro (2012), Brenner, Watkins, dan Flynn (2012), Agustina dan Susilawati (2012), dan Sapariyah, Setyorini dan Dharma (2016). Penelitian-penelitian tersebut menggunakan beberapa variabel atau faktor yang memengaruhi perilaku etis antara lain: gender, locus of control, equity sensitivity, kecerdasan individu, muatan etika, lingkungan, dan budaya etis.

Tikollah et al. (2006) menyebutkan bahwa perilaku etis seseorang dikelompokkan ke dalam 3 (tiga) aspek, yaitu: aspek individual (religiusitas, kecerdasan emosional, gender, iklim etis individu, sifat- sifat personal dan kepercayaan bahwa orang lain lebih tidak etis), aspek organisasi (suasana etis organisasi, dan suasana organisasi), dan aspek lingkungan (lingkungan organisasi dan lingkungan sosial). Dalam penelitiannya, Tikollah et al. (2006) mengkaji perilaku etis mahasiswa akuntansi pada dimensi kecerdasan intelektual (IQ), kecerdasan emosional (EQ), dan kecerdasan spiritual (SQ). Hasil penelitiannya menunjukkan bahwa kecerdasan intelektual memengaruhi sikap dan perilaku etis, sedangkan kecerdasan emosional dan kecerdasan spiritual tidak memengaruhi perilaku etis. Hasil penelitian lain yang dilakukan oleh Maryani dan Ludigdo (2001) menunjukkan bahwa faktor-faktor yang memengaruhi perilaku etis akuntan adalah faktor religiusitas, pendidikan, organisasional, kecerdasan emosional dan lingkungan keluarga. Sedangkan penelitian Brenner, Watkins dan Flynn (2012) menunjukkan bahwa sikap atau perilaku etis mahasiswa dipengaruhi oleh orang tua dan instrospeksi. Upaya yang dinilai efektif untuk memperbaiki, meningkatkan, ataupun solusi dilema etika yaitu dengan aktivitas pendidikan, religius atau keagamaan (Brenner, Watkins, dan Flynn, 2012), dan menjadikan nilai (Islam) sebagai filter mekanisme berfikir dalam proses pendidikan akuntansi (Rahman, 2003).

Selain faktor individu, terdapat aspek lain yang dinilai berpengaruh terhadap perilaku atau sikap etis mahasiswa akuntansi, yaitu pemberian muatan etika dan penciptaan budaya etis dalam keluarga. Pemberian muatan etika diharapkan dapat mengembangkan kapasitas pembelajaran, pemikiran logika teori, dan analisa kritis mahasiswa akuntansi. Namun, realitasnya menunjukkan bahwa pemberian muatan etika dinilai masih kurang dalam kurikulum akuntansi (Ludigdo dan Machfoedz, 1999; Sari, 2012). Konsekuensi logis minimnya pemberian muatan etika dalam kurikulum pendidikan akuntansi akan membawa values (nilai-nilai) "sekularisasi" yang berciri khas self-interest, menekankan bottom line laba dan hanya mengakui realitas yang tercandra (materialistik) (Mulawarman, 2008). Selanjutnya, disarankan untuk mengintegrasikan etika ke dalam mata kuliah tertentu (Ludigdo dan Machfoedz, 1999). Dengan demikian, pemberian muatan etika disinyalir berdampak terhadap perilaku etis mahasiswa akuntansi ke depan. Sebagaimana penelitian yang dilakukan oleh Triani (2011), Sari (2012) dan Agustina (2012) menunjukkan hasil bahwa muatan etika berpengaruh terhadap sikap (perilaku) etis. Sedangkan Sapariah, Setyorini dan Dharma (2016) yang menunjukkan hasil yang sebaliknya dimana muatan etika dan budaya etis tidak memengaruhi sikap atau perilaku etis mahasiswa akuntansi.

Berdasarkan beberapa penelitian tersebut di atas, menunjukkan hasil yang berbeda-beda dan masih terbatasnya penelitian yang menguji faktor non individual seperti budaya etis (individu) dan pemberian muatan etis yang memengaruhi sikap (perilaku) etis. Selain itu, budaya etis dalam penelitian sebelumnya hampir semuanya menggunakan unit analisis budaya organisasi, namun dalam penelitian ini peneliti memodifikasinya dengan menggunakan budaya etis di lingkungan keluarga. Hal tersebut dilakukan dengan argumentasi bahwa penelitian ini dilakukan hanya pada satu pendidikan vokasi akuntansi 
di Yogyakarta dan unit terkecil yang diteliti adalah individu sehingga agar mempunyai keberdayabandingan data maka budaya etis dimodifikasi menjadi budaya etis keluarga dan bukan organisasi.

Oleh karena itu, penelitian ini dimaksudkan untuk mengembangkan dan menguji kembali dengan mengkompilasi hasil dari beberapa penelitian sebelumnya yang sejenis. Penelitian ini difokuskan untuk mengkaji secara empiris interaksi budaya etis dan kecerdasan spiritual pada hubungan antara muatan etis terhadap sikap (perilaku) etis mahasiswa pendidikan vokasi akuntansi di Yogyakarta. Hasil penelitian ini diharapkan dapat menggeneralisasi dan mengembanhkan hasil penelitian sebelumnya. Selain itu juga diharapkan berkontribusi dalam memberikan rekomendasi strategis bagi para pengambil kebijakan dalam mempertimbangkan perlunya internalisasi dan integrasi muatan-muatan etika serta mekanismenya dalam proses pendidikan akuntansi khususnya di perguruan tinggi. Selain itu, hasil penelitian ini diharapkan memberikan kontribusi positif dalam pengembangan akuntansi keperilakuan khususnya etika.

\section{KAJIAN TEORI}

\subsection{Teori Perkembangan Moral Kognitif}

Peneliti yang pertama mengemukakan mengenai perkembangan moral (moral development) dalam monografnya "The Moral Judgment of a Child" adalah Piaget pada tahun 1932. Dalam perkembangannya menurut Kohlberg tahun 1984 (www.wikipedia.org), teori perkembangan moral berkembang menjadi teori perkembangan kogntif (cognitive moral development-CMD) modern yang diciptakan oleh Lawrence Kohlberg pada tahun 1950an. Penemuan tersebut merupakan pengembangan dari gagasan Piaget sehingga mencakup penalaran remaja dan orang dewasa. Berbeda dengan rerangka filsafat moral yang hanya mengevaluasi sikap sadar tergadap perilaku etis, teori perkembangan moral kognitif bergerak lebih dalam ke lapisan bawah sadar jiwa manusia. Teori perkembangan moral kognitif menurut Mintchik dan Farmer pada tahun 2009 (dalam id.wikipedia.org), CMD menekankan pada proses berpikir moral (moral thought process), apa yang dipikirkan seorang individu dalam menghadapi sebuah dilema etika.

Riset yang dikembangkan oleh Kohlberg pada tahun 1963 dan 1964 merupakan awal dikenalnya teori perkembangan moral kognitif ke masyarakat. Menurut prospektif, pengembangan moral kognitif, kapasitas moral individu menjadi lebih kompleks jika individu tersebut mendapatkan tambahan struktur moral kognitif pada setiap level pertumbuhan perkembangan moral. Terdapat 3 aspek yang membedakan pertimbangan etis dengan semua proses mental lainnya. Aspek-aspek tersebut adalah: (1) kognisi (cognition) berdasarkan pada nilai dan bukan pada fakta yang tidak nyata, (2) penilaian didasarkan atas beberapa isu yang melibatkan diri sendiri dan orang lain, (3) penilaian didasarkan atas beberapa isu "seharusnya" daripada berdasarkan kesukaan biasa atau urutuan pilihan (Colby dan Kohlberg, 1987 dalam Richmond 2001).

Selain mengembangkan teori Piaget, Kohlberg juga mengembangkan teori perkembangan kognitifnya Dewey. Dalam teorinya, Kohlberg menyatakan bahwa personal value diperoleh melalui suatu proses berpikir dan berpendapat. Sebuah kejadian penting akan menolong masyarakat untuk meningkatkan kemampuan moralnya dan ini tercermin dari pengalaman konfliknya dalam menjelaskan opini mereka ketika berinteraksi dengan seseorang yang mempunyai tingkatan moral lebih tinggi (Cherington, 1994). Ada enam tingkatan dalam Teori Kohlberg (Ponemeon, 1992), yaitu: tahap pertama dan kedua dari perkembangan moral, disebut dengan Pre-coventional, orang (biasanya anak-anak) membuat keputusan-keputusan moral berdasarkan pada imbalan dan hukuman. Tahap tiga dan empat disebut Conventional, dalam tahap ini seseorang sudah memperhatikan aturan-aturan sosial dan kebutuhan-kebutuhan sesama. Tahap kelima dan keenam disebut Post-conventional, dimana kebaikan bagi masyarakat telah dimasukkan dalam pemikiran moral. 
Asumsi-asumsi yang digunakan Kohlberg dalam mengembangkan teorinya sebagai berikut: (a) bahwa kunci untuk dapat memahami tingkah laku moral seseorang adalah dengan memahami filsafat moralnya, yakni dengan memahami alasan-alasan yang melatarbelakangi perbuatannya, (b) tingkat perkembangan tersusun sebagai suatu keseluruhan cara berpikir. Setiap orang akan konsisten dalam tingkat pertimbangan moralnya, (c) konsep tingkat perkembangan moral menyatakan rangkaian urutan perkembangan yang bersifat universal, dalam berbagai kondisi budaya (Falah, 2007). Teori Kohlberg telah dipakai Trevino (1986) dalam mengidentifikasi pengaruh individu terhadap keputusan etis. Demikian pula, Ferrel dan Gresham (1986) dan Hunt dan Vitell (1986), memasukkan variabel personal value dalam pengambilan keputusan, meskipun telah dijelaskan pula bahwa budaya etis organisasi sebagai faktor organisasional berpengaruh pada perilaku etis seseorang.

Selanjutnya penelitian-penelitian Kohlberg dikembangkan oleh James Rest (1986) dalam Richmond (2001). Pengembangan yang dilakukan adalah dalam hal validitas, instrumen yang reliabel untuk mengukur pertimbangan etis. Ada 4 komponen Rest (1979) dalam Richmond (2001) mendeskripsikan bahwa proses sebagiana besar individual menggunakannya dalam pembuatan keputusan dan perilaku. Model empat komponen juga menggambarkan bagaimana struktur kognitif bergabung menjadi satu proses alasan ketika dihadapkan dengan dilema etika.

\subsection{Perilaku Etis}

Etika merupakan filsafat atau pemikiran kritis dan mendasar tentang ajaran-ajaran dan pandangan-pandangan moral (Tikollah et al. 2006). Etika sebagai refleksi moralitas dapat dicermati dari berbagai dimensi, tergantung persoalan moral yang akan dikritisi (Ludigdo, 2006). Etika merupakan tingkah laku atau aturan-aturan tingkah laku yang diterima dan digunakan oleh individu atau suatu golongan tertentu (Komsyah dan Indriantoro, 1998). Etika meliputi suatu proses penentuan yang kompleks tentang apa yang seharusnya dilakukan seseorang dalam situasi tertentu yang disifati oleh kombinasi dari pengalaman dan pembelajaran masing-masing individu (Ward et al. 1993 dalam Tikollah et al. 2006). Dengan demikian, etika dijadikan prinsip moral dan landasan berperilaku yang terpuji bagi individu. Etika erat kaitannya dengan hubungan antar manusia dan berfungsi untuk mengarahkan perilaku bermoral. Sebagaimana dikutip dalam Kamus Besar Bahasa Indonesia, kata moral berarti ajaran mengenai baik buruknya perbuatan, kewajiban, sikap, akhlak, budi pekerti, dan susila.

Keraf (1998) menjelaskan, secara umum etika dibagi atas etika umum dan etika khusus. Etika umum berkaitan dengan bagaimana manusia mengambil keputusan keputusan etis, teori- teori etika dan prinsip-prinsip moral dasar yang menjadi pegangan bagi manusia dalam bertindak, serta tolok ukur dalam menilai baik atau buruknya suatu tindakan. Sedangkan etika khusus adalah penerapan prinsip-prinsip moral dasar dalam bidang kehidupan yang khusus. Etika khusus terdiri atas tiga kelompok, yaitu etika individual, etika lingkungan hidup dan etika sosial. Etika individual berkaitan dengan kewajiban dan sikap manusia terhadap dirinya sendiri. Etika sosial yang berkaitan dengan kewajiban, sikap dan pola perilaku manusia dengan manusia lainnya. Salah satu bagian dari etika sosial adalah etika profesi, termasuk didalamnya etika profesi akuntan. Etika profesi menekankan tuntutan terhadap profesi seseorang sehubungan dengan keahlian dan komitmen moral seperti tanggung jawab, keseriusan, disiplin dan intergritas moral (Hastuti, 2007).

Etika dalam suatu organisasi profesi dituangkan dalam aturan tertulis yang disebut kode etik. Kode etik tersebut dijadikan sebagai pegangan bagi anggota profesi dalam menjaga reputasi dan kepercayaan masyarakat agar profesi tetap eksis dan bertahan (Tikollah et al. 2006). Sebagai organisasi profesi di bidang akuntansi, Ikatan Akuntan Indonesia (IAI) memiliki kode etik yang terbagi atas delapan prinsip etika, yaitu: tanggung jawab profesi, kepentingan umum (publik), integritas, objektifitas, kompetensi dan kehati-hatian professional, kerahasiaan, perilaku professional, dan standar teknis. 
Larkin (2000) dalam Hastuti (2007) menjelaskan bahwa kemampuan untuk mengidentifikasi perilaku etis dan tidak etis pada suatu profesi sangat penting, karena kepercayaan masyarakat terhadap profesi akan rusak apabila seseorang melakukan tindakan- tindakan yang tidak etis. Jika seorang auditor melakukan tindakan-tindakan yang tidak etis, maka akan merusak kepercayaan masyarakat terhadap profesi auditor tersebut (Khomsiyah dan Indriantoro, 1998).

Perilaku beretika merupakan hal yang penting bagi masayarakat agar kehidupan berjalan dengan tertib. Socrates dalam Falah (2006) menyatakan bahwa yang dimaksud dengan tindakan etis adalah tindakan yang didasarkan pada nilai-nilai kebenaran. Etika sebagai bidang studi menentukan standar untuk membedakan antara karakter yang baik dan tidak baik atau dengan kata lain etika merupakan studi normatif mengenai berbagai prinsip yang mendasari tipe-tipe tindakan manusia. Suseno dalam Tikollah (2006) menjelaskan bahwa etika merupakan filsafat atau pemikiran kritis dan mendasar memnegani ajaranajaran dan pandangan-pandangan moral. Etika sebagai refleksi moralitas dapat dicermati dari berbagai dimensi, tergantung persoalan moral yang akan dikritisi (Ludigdo, 2006).

Etika merupakan suatu prinsip moral dan perbuatan yang menadi landasan bertindak seseorang sehingga apa yang dilakukan dipandang oleh masyarakat sebagai perbuatan terpuji dan meningkatkan martabat dan kehormatan seseorang (Munawir, 1997). ETika sangat erta kaitannya dengan hubungan yang mendasar antar manusia dan berfungsi untuk mengarahkan perilaku bermoral. Moral sebagai sikap mental dan emosional yang dimiliki individu sebagai anggota kelompok sosial dalam melakukan tugas-tugas atau fungsi yang diharuskan serta loyalitas pada kelompok. Etika meliputi suatu proses penentuan yang kompleks tentang apa yang harus dilakukan seseorang dalam situasi tertentu. Proses itu sendiri meliputi penyeimbangan pertimbangan sisi dalam (inner) dan sisi luar (outer) yang disifati oleh kombinasi unik dari pengalaman dan pembelajaran masing-masing individu. Perilaku moral disini lebih terbatas pada pengertian yang meliputi kekhasan pola etis yang diharapkan untuk profesi tertentu. Ada enam nilai etika utama menurut Josephson Institute, dalam Arens (2012): (1) Dapat dipercaya (trustworthiness) termasuk kejujuran, integritas, keandalan, dan kesetiaan, (2) Rasa hormat (respect) termasuk nilai kesopanan, kepatuhan, penghormatan, toleransi, dan penerimaan, (3) Tanggungjawab (responsibility), tanggungjawab terhadap tindakan yang dilakukannya dan memberikan batasan, (4) Kewajaran (fairness), termasuk keadilan dalam mengatasi masalah, (5) Kepedulian (caring)berarti secara tulus memperhatikan kebutuhan dan kesejahteraan orang lain, (6) Kewarganegaraan (citizenship), termasuk mematuhi peraturan dan norma yang telah ditetapkan.

Jika membahas mengenai perilaku dan keinginan untuk mengubah perilaku atau menciptakan perilaku yang diinginkan, maka hal penting yang harus difahami adalah faktor-faktor apa saja yang memengaruhi perilaku dan seberapa kuat pengaruh itu (Ustadi, 2005). Indikator-indikator perilaku etis menurut Eileen Rahman (2006) dalam Himaya (2013) adalah: (a) Memahami dan mengenali perilaku sesuai kode etik yaitu mengikuti kode etik profesi, jujur dalam mengelola dan menggunakan sumber daya dalam lingkup otoritasnya dan memastikan apa yang dilakukan tidak melanggar kode etik, (b) Melakukan tindakan yang konsisten dengan nilai dan keyakinan, (c) Bertindak menurut nilai dan norma meskipun hal tersebut sulit, (d) Bertindak berdasarkan nilai dan norma meskipun ada resiko dan biaya yang cukup besar.

\subsection{Muatan Etika}

Pendidikan tinggi akuntansi saat ini memegang peranan strategis. Pendidikan tinggi akuntansi termasuk vokasi mempunyai tugas menghasilkan akuntan profesional yang kompeten dan beretika moral tinggi, karena dalam proses pendidikan itulah para calon akuntan dibentuk. Untuk mewujudkan hal tersebut, salah satu upaya penting yang dapat dilakukan adalah memberikan muatan etika dalam proses pendidikan akuntansi. Semakin proses pendidikan bagus, maka kualitas akuntan yang dihasilkannyapun akan bagus. Sebagaimana diungkapkan Machfoedz dalam Efendi (2001:1) bahwa kualitas akuntan 
yang dihasilkan pendidikan tinggi akuntansi tergantung pada proses belajar mengajar yang dilakukannya.

Utami dan Indriawati (2006) mengemukakan bahwa memasukkan aspek etika langsung pada mata kuliah akuntansi keuangan sangat membantu mahasiswa untuk mempertajam kepekaan mereka terhadap isu-isu etika yang terjadi dalam dunia akuntansi. Selain itu, Siagian dalam Utami dan Indriawati (2006) mengemukakan bahwa dunia pendidikan memiliki pengaruh yang besar terhadap perkembangan kesadaran sikap etis seseorang, demikian halnya dengan pendidikan akuntansi sangat berpengaruh terhadap perilaku etis akuntan masa depan.

\subsection{Kecerdasan Spiritual}

Kecerdasan spiritual merupakan gabungan hakikat dengan kekuatan daya mental seseorang (Levin, 2005). Khavari dalam Hanafi (2010) mengatakan bahwa kecerdasan spiritual adalah dimensi non materi seperti jiwa manusia yang dapat digambarkan sebagai berlian kasar yang telah ada pada semua manusia. Kecerdasan spiritual ini dapat ditingkatkan dan menurun, ke,a,puan untuk meningkatkan kecerdasan spiritual yidak terbatas.

Kecerdasan spiritual adalah kecerdasan untuk menghadapi dan memecahkan persoalan makna dan nilai yang menempatkan perilaku dan hidup manusia dalam konteks yang lebih luas yang memungkinkan seseorang untuk menyatukan hal-hal yang bersifat intrapersonal dan interpersonal serta menjembatani kesenjangan antara diri sendiri dan orang lain (Agustini, 2013). Sejalan dengan hal itu, Zohar dan Marshall (2002) juga mengemukakan bahwa kecerdasan spiritual merupakan kecerdasan untuk menghadapi dan memecahkan persoalan makna dan nilai untuk menempatkan perilaku dan hidup sesorang dalam konteks makna yang lebih luas dan lebih bermakna.

Clausen dalam Masaong dan Tilome (2011) menggambarkan kecerdasan spiritual sebagai wawasan pemikiran yang luar biasa mengagumkan dan sekaligus argumen pemikiran betapa pentingnya hidup sebagai manusia spiritual yang cerdas. Wujud dari kecerdasan spiritual ini adalah sikap moral yang dipandang luhur oleh pelaku (Ummah et el. 2003:43 dalam Tikollah et al. (2006).

Menurut Zohar dan Marshal (2002) indikator kecerdasan spiritual meliputi: (1) Kemampuan untuk bersikap fleksibel, (2) Adanya tingkat kesadaran diri yang tinggi, (3) Kemampuan menghadapi dan memanfaatkan penderitaan yang dihadapi, (4) Kemampuan menghadapi dan melampaui rasa sakit, (5) Kualitas hidup yang diilhami oleh visi dan nilai-nilai, (6) kecenderungan berpandangan holistik, (7) Memiliki kemudahan untuk bekerja dan berinteraksi melawan konvensi.

Dengan kecerdasan spiritual memungkinkan lahirnya wawasan dan pemahaman untuk menemukan makna akan keberadaan seseorang, tempat bertindak, berpikir, dan merasakan sesuatu. Dengan kecerdasan spiritual maka mahasiswa akuntansi dapat menghayati arti dari pentingnya sopan santun, toleran, dan beradap dalam hidup. Hal ini menjadi panggilan intrinsik dalam etika sosial, karena sepenuhnya manusia sadar bahwa ada makna simbolik kehadiran Tuhan dalam kehidupan sehari-hari yang selalu mengawasi manusia dimana saja dan kapanpun.

\subsection{Budaya Etis}

Kemampuan seorang profesional, termasuk akuntan untuk dapat peka dan mengerti terhadap persoalan etika sangat dipengaruhi juga oleh lingkungan dimana yang bersangkutan berada. Menurut Hunt et al. (1989) menyatakan bahwa lingkungan sangat memengaruhi keputusan etis seseorang. Lingkungan paling kecil dan paling dekat dengan seseorang adalah lingkungan keluarga.

Pada setiap keluarga dapat dipastikan mempunyai nilai-nilai yang diyakini untuk dijadikan panduan bagi anggota keluarganya dalam bertindak dan berperilaku seharihari.Nilai-nilai baik keluarga yang terus dipegang dan dipedomani pada akhirnya akan menjadi budaya etis dalam keluarga tersebut. 
Menurut Douglas et al. (2001), budaya merupakan sistem nilai yang bersifat umum. Sedangkan budaya etis merupakan standar yang mengatur adaptasi internal dan eksternal seseorang (Schein, 1985). Dengan demikian, budaya etis keluarga dapat didefinisikan peneliti sebagai sistem nilai dasar yang menjadi standar anggota keluarga dalam berinteraksi di dalam maupundi luar keluarga.

Beberapa penelitian telah dilakukan yang menunjukkan pengaruh budaya etis terhadap perilaku etis walaupun dalam lingkup organisasi. Hasil penelitian Hunt et al. (1989) menemukan bahwa budaya etis mempunyai pengaruh yang kuat dalam membentuk perilaku dan pertimbangan etis semua orang. Ziegenfuss (2000) mengungkapkan bahwa budaya etis mempunyai pengaruh yang lemah pada pertimbangan etis dalam lingkup organisasi. Sedangkan Douglas et al. (2001) meneliti mengenai The Effect of Organizational Culture and Ethical Orientation on Accountants Ethical Judgements ditemukan adanya pengaruh antara budaya etis terhadap pertimbangan etis dalam lingkup organisasi.Demikian halnya penelitian yang dilakukan Aras (2001) dan Vitell (2006) juga menemukan bahwa budaya etis berpengaruh kuat pada perilaku etis.

\subsection{Review Penelitian Sebelumnya}

Berbagai penelitian relevan mengenai muatan etika dan perilaku etis telah dilaksanakan. Salah satu diantaranya yang dilakukan oleh Sari (2013) meneliti mengenai pengaruh muatan etika dalam pendidikan akuntansi terhadap persepsi etika mahasiswa pada FEB Unibraw Malang. Hasil penelitian menunjukkan bahwa muatan etika dalam pendidikan akuntansi mempunyai pengaruh signifikan terhadap persepsi etika mahasiswa.

Sapariyah et al. (2016) meneliti mengenai pengaruh muatan etika dalam pengajaran akuntansi keuangan, kecerdasan intelektual, kecerdasan emosional, dan kecerdasan spiritual terhadap sikap etis mahasiswa akuntansi. Hasil penelitian menunjukkan bahwa muatan etika dalam pengajaran akuntansi keuangan dan kecerdasan emosional berpengaruh positif dan signifikan terhadap sikap etis mahasiswa akuntansi. Sedangkan kecerdasan intelektual berpengaruh namun tidak signifikan terhadap sikap etis mahasiswa. Kecerdasan spiritual berpengaruh negatif tetapi tidak signifkan terhadap sikap etis mahasiswa.

Tikollah et al. (2006) meneliti mengenai pengaruh kecerdasan intelektual, kecerdasan emosional, dan kecerdasan spiritual terhadap sikap etis mahasiswa akuntansi pada Perguruan Tinggi Negeri Di Sulawesi Selatan menunjukkan bahwa IQ, EQ, dan SQ secara simultan berpengaruh signifikan terhadap sikap etis mahasiswa akuntansi. Akan tetapi, secara parsial hanya IQ yang berpengaruh signifikan terhadap sikap etis mahasiswa akuntansi.

Utami dan Indriawati (2006) meneliti mengenai Muatan Etika dalam Pengajaran Akuntansi Keuangan dan Dampaknya terhadap Persepsi Etika Mahasiswa dengan melakukan eksperimen semu. Hasil penelitian menunjukkan bahwa muatan etika tidak berpengaruh terhadap persepsi etika mahasiswa. Sedangkan interaksi antara muatan etika pada pelajaran akuntansi keuangan dan Indeks Prestasi Kumulatif mahasiswa berpengaruh signifikan terhadap persepsi etika mahasiswa.

Agustina dan Susilawati (2012) meneliti mengenai dampak muatan etika dalam pengajaran akuntansi keuangan dan Audit terhadap Persepsi Etika Mahasiswa yang dimoderasi oleh kecerdasan kognisi dan kecerdasan emosional. Penelitian tersebut merupakan studi eksperimen semu. Hasil penelitian menunjukkan bahwa muatan etika dalam pengajaran akuntansi keuangan dan audit tidak memengaruhi persepsi etika mahasiswa. Interaksi antara muatan etika dalam pengajaran akuntansi keuangan dan Indeks Prestasi Akademik secara signifikan memengaruhi persepsi etis mahasiswa.

Apriliawati dan Suardana (2016) meneliti mengenai budaya etis organisasi sebagai variabel pemoderasi pengaruh orientasi etis pada pertimbangan etis auditor di Bali. Hasil penelitian menunjukkan bahwa budaya etis organisasi mampu memoderasi pengaruh orientasi etis pada pertimbangan etis auditor.

Yunika (2014) meneliti mengenai pengaruh muatan etika dalam pengajaran akuntansi 
keuangan dan prestasi mahasiswa terhadap persepsi etika mahasiswa Fakultas Ekonomi UNIBA. Hasil penelitian menunjukkan bahwa muatan etika dalam pengajaran akuntansi secara parsial berpengaruh terhadap persepsi etis mahasiswa. Sedangkan Indeks Prestasi Mahasiswa menunjukkan tidak ada pengaruh terhadap persepsi etika mahasiswa.

Penelitian Sapariyah et al. (2016) mengenai pengaruh muatan etika dalam pengajaran akuntansi keuangan, kecerdasan intelektual, dan kecerdasan emosional, dan kecerdasan spiritual terhadap sikap etis mahasiswa akuntansi di Surakarta. Hasil penelitian menunjukkan bahwa muatan etika dalam pengajaran akuntansi keuangan dan kecerdasan emosional berpengaruh positif dan signifikan terhadap sikap etis mahasiswa akuntansi. Kecerdasan intelektual menunjukkan adanya pengaruh positif namun tidak signifikan terhadap sikap etis mahasiswa akuntansi, sedangkan kecerdasan spiritual menunjukkan pengaruh negatif dan tidak signifkan terhadap sikap etis mahasiswa akuntansi.

Penelitian yang dilakukan Lucyanda dan Endro (2012) mengenai faktor-faktor yang mempengaruhi perilaku etis mahasiswa akuntansi di Universitas Bakrie Jakarta menunjukkan hasil hanya kecerdasan emosional yang berpengaruh terhadap perilaku etis mahasiswa. Sedangkan locus of control dan kecerdasan spiritual tidak berpengaruh terhadap perilaku etis mahasiswa.

Ustadi dan Utami (2005) mengenai analisis faktor individual terhadap perilaku etis mahasiswa, menjelaskan bahwa individu yang memiliki internal locus of control cenderung berperilaku etis dibandingkan individu yang memiliki eksternal locus of control.

\subsection{Kerangka Pemikiran dan Pengembangan Hipotesis}

\subsubsection{Muatan Etika dan Perilaku Etis}

Etika merupakan cabang ilmu yang membahas mengenai perilaku manusia, mengenai apa yang baik dan tidak baik dalam konteks hubungan (Agoes dan Ardana, 2011). Dalam berprofesi, akuntan berpedoman pada etika profesi akuntan. Mautz dan Sharaf (1993) menjelaskan bahwa etika profesi akuntan merupakan panduan bagi perilaku akuntan dan sebagai bentuk pertanggungjawaban terhadap klien, masyarakat, anggota profesi dan dirinya sendiri.

Terkait dengan hal tersebut, maka pendidikan akuntansi sebagai penghasil akuntan profesional tidak hanya menekankan pada pengembangan skills dan knowledge saja, tetapi juga membekalinya dengan pemahaman atas standar etis dan komitmen profesional (Mintz, 1995 dalam Ustadi dan Utami, 2005). Dengan demikian, memberikan pemahaman etika dengan memasukkan muatan-muatan etika moral secara langsung ke dalam mata kuliah sangat penting dilakukan. Sehingga terbangun dunia pendidikan yang etis dan bermoral serta terbentuk masyarakat madani (Utami, 2005). Proses pembelajaran dalam ranah pendidikan akuntansi sudah saatnya mengandung nilai-nilai atau muatan etika holistik, yaitu nilai-nilai akuntabilitas moralitas akuntansi yang dilakukan melalui proses sinergi rasio dan intuisi menuju nilai spiritual (Mulawarman dan Ludigdo, 2010).

Berbagai cara yang dapat dilakukan dalam upaya menginternalisasi muatan etika dalam proses pendidikan, sebagaimana yang diungkapkan Triyuwono (2010) mengenai implementasi sistem pendidikan akuntansi di Fakultas Ekonomi dan Bisnis Universitas Brawijaya Malang yang memuat aspek sosio-spiritualitas dalam pendekatan aspek pembelajaran dengan menggunakan olah akal, olah rasa, dan olah bathin. Dari ketiga pendekatan tersebut, olah rasa berkaitan dengan perasaan (feelings) menjadi lebih sensitif. Dalam olah rasa ini tidak melakukan fungsinya melalui proses berpikir, analisa dan sintesa, yang ada hanya merasakan. Kamayanti (2012) dalam penelitiannya melakukan upaya menginternalisasi Pancasila untuk menghasilkan akuntan yang mempunyai kesadaran utuh melalui pendekatan dialogis. Dan hasilnya menunjukkan bahwa proses dialogis memunculkan banyak kesadaran mahasiswa. Kesadaran ketuhanan atau spiritual muncul saat mahasiswa mendiskusikan pentingnya Tuhan secara teks dan konteks dalam akuntansi. Kesadaran keIndonesiaan muncul saat mahasiswa secara kritis menginginkan jalan keluar bagi keterjebakan akuntansi. Kesadaran kebersamaan dan kemanusiaan 
muncul saat mahasiswa menggunakan rasa dan intuisi untuk menciptakan nilai dalam akuntansi. Kesadaran berbuat adil muncul saat diskusi mengarah pada tujuan akuntansi konvensional, keberpihakan serta pembacaan terhadap dunia. Kamayanti (2012) dalam penelitiannya tersebut menunjukkan bahwa internalisasi nilai moral (Pancasila) melalui pendekatan dialogis akan melahirkan banyak kesadaran dalam diri mahasiswa yang akhirnya disinyalir mampu menghasilkan akuntan yang berkesadaran utuh. Internalisasi nilai atau masuknya aspek etika dalam pengajaran Akuntansi dapat membantu tingkat sensitifitas mahasiswa terhadap pembentukan moral judgement dan moral perception (Yunika et al. 2014) Dengan demikian, pemberian muatan etika (internalisasi nilai) diyakini dapat meningkatkan perilaku etis mahasiswa.

Beberapa riset yang berupaya mengkaji muatan etika terhadap perilaku etis mahasiswa telah dilakukan, seperti Agustina dan Susilawati (2012); Sari, L. P. (2013); dan. Hasil penelitian Sari, L. P. (2013) menunjukkan bahwa muatan etika dalam pendidikan akuntansi mempunyai pengaruh signifikan terhadap persepsi mahasiswa. menunjukkan bahwa muatan etika dalam pendidikan akuntansi mempunyai pengaruh terhadap perilaku mahasiswa. Sedangkan Utami dan Indriawati (2006) menunjukkan sebaliknya. Berdasarkan pada uraian di atas, maka dapat dirumuskan hipotesis sebagaimana berikut:

\section{H1: Muatan Etika berpengaruh terhadap Perilaku Etis Mahasiswa}

\subsubsection{Interaksi Kecerdasan Spritual, Muatan Etika, dan Perilaku Etis}

Kecerdasan individu yang dimiliki seorang (mahasiswa) dinilai dapat menguatkan interaksi antara muatan etika, gender, dan budaya etis terhadap perilaku etis. Ada 3 jenis kecerdasan individu, yaitu kecerdasan intelektual (IQ), kecerdasan emosional (EQ), dan kecerdasan spiritual (SQ). Penelitian ini hanya difokuskan pada SQ saja karena kecerdasan tersebut merupakan kecerdasan tertinggi yang menjadi landasan untuk memfungsikan IQ dan EQ secara efektif (Dwijayanti, 2009 dalam Lucyanda dan Endro, 2012).

Kecerdasan spiritual (SQ) merupakan kemampuan untuk memberikan makna spiritual terhadap pemikiran, perilaku, dan kegiatan, serta mampu mensinergikan berbagai jenis kecerdasan individu dalam konteks yang luas (Zohar dan Marshall, 2001). Lebih lanjut bahwa kecerdasan spiritual disimbolkan sebagai teratai diri yang menggabungkan tiga kecerdasan dasar manusia (rasional, emosional dan spiritual) yang dapat membantu manusia menyembuhkan dan membangun diri secara utuh. Jadi, Kecerdasan spiritual merupakan kecerdasan yang tertumpu pada bagian dalam diri yang berhubungan dengan kearifan di luar ego atau jiwa sadar, sehingga kecedasan spiritual menjadikan manusia yang benar-benar utuh secara intelektual, emosional dan spiritual. Indikasi dari SQ yang telah berkembang dengan baik mencakup: (a) kemampuan untuk bersikap fleksibel; (b) adanya tingkat kesadaran diri yang tinggi; (c) kemampuan untuk menghadapi dan memanfaatkan penderitaan; (d) kemampuan untuk menghadapi dan melampaui perasaan sakit; (e) kualitas hidup yang di ilhami oleh visi dan nilai- nilai; (f) keengganan untuk menyebabkan kerugian yang tidak perlu; (g) kecenderungan untuk berpandangan holistik; (h) kecenderungan untuk bertanya "mengapa" atau "bagaimana jika" dan berupaya untuk mencari jawaban-jawaban yang mendasar; dan (i) memiliki kemudahan untuk bekerja melawan konvensi (Zohar dan Marshall, 2001).

IQ dan EQ tidaklah cukup untuk membawa diri seseorang mencapai kebahagian dan kebenaran hakiki, karena ada nilai-nilai lain yang tidak bisa dipungkiri keberadaannya sebagaimana tercakup dalam SQ (Tikollah et al. 2006). Kecerdasan spiritual (SQ) merupakan kecerdasan tertinggi yang menjadi landasan untuk memfungsikan IQ dan EQ secara efektif sehingga mampu memberikan makna spiritual terhadap pemikiran dan perilaku etis individu, termasuk mahasiswa akuntansi.

Beberapa penelitian sebelumnya menunjukkan bahwa hanya faktor religiusitas (kecerdasan spiritual) yang memengaruhi sikap etis akuntan (Maryani dan Ludigdo, 2001). Hal senada dikemukakan dari hasil penelitian Ramly, Chai dan Lung (2008) yang menunjukkan bahwa religiusitas (kecerdasan spiritual) berpengaruh positif terhadap 
perilaku etis mahasiswa universitas di Malaysia. Demikian halnya dengan Tikollah et al. (2006); Lisda (2009); Agustini dan Herawati (2013); dan Oktawulandari (2015). Namun bertolak belakang dengan hasil penelitian Lucyanda dan Endro (2012).

Dengan demikian, apabila muatan etika dinilai dapat memengaruhi perilaku etis mahasiswa, maka logis pulalah jika kecerdasan spiritual disinyalir mampu memperkuat hubungan diantara pemberian muatan etika dengan perilaku etis mahasiswa. Dengan kata lain, terjadi saling interaksi yang disinyalir mampu saling menguatkan ataupun melemahkan hubungan diantara mereka. Sebagaimana telah dijelaskan sebelumnya bahwa kecerdasan spiritual merupakan kecerdasan tertinggi dan melandasi berfungsinya dua kecerdasan yang lain yang mampu membawa individu pada kebahagiaan yang hakiki. Jadi pengaruh atau hubungan antara muatan etika dengan perilaku etis mahasiswa akuntansi diduga akan semakin kuat apabila diinteraksikan dengan kecerdasan spiritual. Jadi hipotesis yang dapat dibangun adalah:

H2: Kecerdasan spiritual memperkuat hubungan antara muatan etika terhadap perilaku etis mahasiswa akuntansi.

\subsubsection{Interaksi Budaya Etis, Muatan Etika, dan Perilaku Etis}

Seorang professional yang dapat mengerti dan sensitif terhadap adanya masalah-masalah atau isu-isu etika dalam profesinya dipengaruhi oleh budaya etis dimana individu tersebut berada. Menurut Schein dalam Falah (2007), budaya etis organisasi adalah standar yang memandu adaptasi eksternal dan internal organisasi. Budaya etis organisasi bertindak sebagai mekanisme alasan yang masuk akal serta kendali yang menuntun dan membentuk sikap dan perilaku orang-orang yang berada di dalamnya. Terciptaya budaya organisasi yang etis akan memengaruhi perilaku etis seseorang dalam melaksanakan tugas (Putra, 2015; Oktawulandari, 2015). Jadi, apabila budaya etis tersebut tercipta di lingkungan perguruan tinggi, maka hal tersebut mencerminkan bahwa kampus sudah sejak dini membekali mahasiswa pengetahuan dan pemahaman mengenai etika dan budaya etis. Dengan demikian, keterjadian pelanggaran etika dalam profesi yang digeluti mahasiswa ke depan dapat diminimalisasi, termasuk dalam profesi akuntansi. Sehingga problematika keterpurukan citra profesi akuntan dan menurunnya kepercayaan masyarakat terhadap profesi dapat terselesaikan.

Budaya etis yang sengaja diciptakan dimaksudkan menjadi standar minimal individu dalam bertindak dan bertingkah laku dimana saja termasuk dalam lingkungan keluarga. Budaya etis akan memandu orang-orang yang berada dalam lingkungan tertentu ketika membuat penilaian dan pertimbangan-pertimbangan etis dalam melaksanakan kegiatannya (Oktawulandari, 2015). Apabila budaya etis tersebut telah terbangun, maka diyakini akan menguatkan upaya internalisasi muatan etis pada proses pendidikan akuntansi di perguruan tinggi dengan perilaku etis mahasiswanya. Sebagaimana dikemukakan Oktawulandari (2015) dan Putra (2015) dari hasil penelitiannya bahwa budaya etis memiliki pengaruh yang kuat terhadap pemikiran dan perilaku orang-orang yang berada di dalam organisasi. Demikian pula dengan penelitian Key (1999), Falah (2006), dan Aprilliawati dan Suardana (2016) yang menunjukkan bahwa budaya etis berpengaruh positif dan signifikan terhadap perilaku etis akuntan. Demikian pula hasil penelitian Martina et al. (2015) yang menunjukkan hasil bahwa budaya etis berpengaruh terhadap sensitivitas etika kegiatan audit yang dilaksanakan inspektorat pemerintah Kabupaten Buleleng. Hal tersebut tak terkecuali terjadi pula pada mahasiswa dalam institusi perguruan tinggi.

Dengan demikian, apabila muatan etika dinilai dapat memengaruhi perilaku etis mahasiswa, maka logis juga apabila budaya etis (dalam keluarga) disinyalir mampu memperkuat hubungan diantara pemberian muatan etika dengan perilaku etis mahasiswa. Dengan kata lain, terjadi saling interaksi muatan etika dan perilaku etis disinyalir akan semakin menguatkan dengan dimoderasi budaya etis. Jadi hipotesis yang dapat dibangun adalah: 


\section{H3: Budaya Etis memperkuat hubungan antara muatan etika terhadap perilaku etis mahasiswa akuntansi.}

Berdasarkan berbagai uraian di atas, maka peneliti mencoba menggambarkan model kerangka pemikiran dalam penelitian ini sebagaimana berikut:

\section{Gambar 1}

Model Kerangka Pemikiran

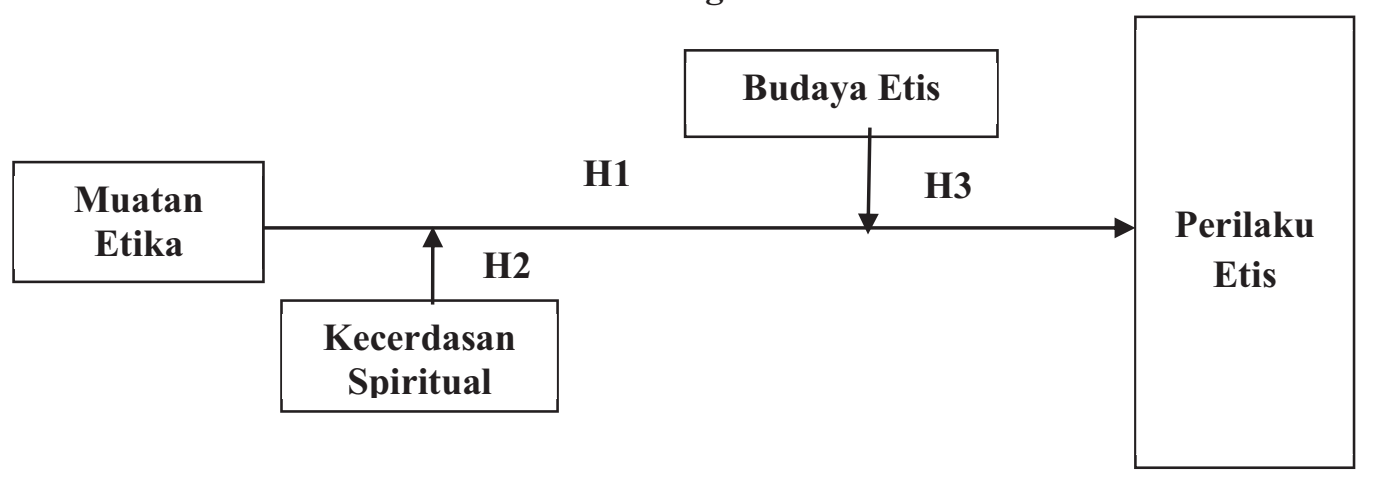

Sumber: Hasil Olahan Peneliti

\section{METODE}

\subsection{Populasi Dan Sampel}

Populasi dalam penelitian ini adalah seluruh mahasiswa di salah satu perguruan tinggi ternama yang menyelenggarakan pendidikan vokasi akuntansi di Yogyakarta, yaitu Akademi Akuntansi YKPN. Pengambilan sampel dilakukan dengan teknik purposive sampling. Adapun kriterianya adalah: Pertama, mahasiswa telah menempuh mata kuliah etika bisnis profesi dan pengauditan yang dinilai lebih relevan dan tepat menjadi target repsonden penelitian ini. Kedua, responden target bersedia berpartisipasi dalam penelitian ini sejumlah 288 mahasiswa yang isian kuesionernya layak diproses dari 368 yang didistribusikan..

\subsection{Sumber data dan Teknik Pengumpulan Data}

Data yang digunakan dalam penelitian adalah data primer yang dikumpulkan dengan menggunakan kusioner. Kuesioner didistribusikan kepada responden target secara langsung atau personal (personally administrated questionnaires) sehingga kuesioner dikembalikan seketika itu juga. Hal tersebut dilakukan dengan harapan memperoleh tingkat pengembalian (response rate) maksimal.

\subsection{Definisi Operasionalisasi Variabel}

Perilaku etis merupakan sikap dan perilaku yang sesuai dengan norma-norma sosial yang diterima secara umum sehubungan dengan tindakan-tindakan yang bermanfaat atau yang membahayakan (Griffin dan Elbert, 1998 dalam Maryani dan Ludigdo, 2001).

Muatan etika didefinisikan sebagai model pembelajaran yang memasukkan aspek muatan etika yang mengintegrasikan tiga potensi kecerdasan manusia dengan olah akal, olah rasa, dan olah bathin (Sari, 2012).

Budaya etis didefinisikan sebagai pandangan luas persepsi individu dalam keluarga pada tindakan orang tua yang sangat consern pada pentingnya etika dalam keluarga dengan memberikan memberikan reward ataupun punishment atas berbagai tindakan tidak etis.

Kecerdasan spiritual merupakan kemampuan untuk menghadapi dan memecahkan persoalan makna dan nilai dengan menempatkan perilaku hidup manusia dalam konteks yang luas (Zohar dan Marshall, 2001). Makna dan nilai yang dimaksudkan disini terkait erat dengan makna ibadah yang diimplementasikan dalam setiap perilakunya. 


\subsection{Teknik Analisis Data}

Teknik analisis data yang digunakan dalam penelitian ini dilakukan dengan beberapa teknik berikut ini, yaitu:

\subsubsection{Uji Kualitas Data}

\section{a. Uji Validitas Data}

Uji validitas digunakan untuk mengukur sah atau tidaknya suatu kuisioner (Ghozali, 2011:54). Suatu kuesioner dikatakan valid jika pernyataan dalam kuesioner mengungkapkan sesuatu yang akan diukur oleh kuesioner tersebut.

\section{b. Uji Reliabilitas Data}

Uji Reliabilitas adalah alat untuk mengukur suatu kuesioner yang merupakan indikator dari variabel atau konstruk (Ghozali, 2011:47). Uji reliabilitas dilakukan untuk mengetahui sejauh mana butir-butir pertanyaan atau pernyataan dalam kuesioner dalam penelitian dapat dipercaya (handal).

\subsubsection{Uji Asumsi Klasik}

Model Regresi linier berganda (multiple regression) dapat disebut sebagai model yang baik jika memenuhi kriteria BLUE (Best Linear Unbiased Estimator) (Falah, 2007). BLUE dapat dicapai apabila memenuhi asumsi klasik. Asumsi klasik dalam penelitian ini adalah:
a. Uji Normalitas Data
b. Uji Multikolinearitas
c. Uji Heteroskedastisitas

\subsubsection{Pengujian Hipotesis}

Pengujian hipotesis dalam penelitian ini menggunakan uji interaksi (moderated regression analysis). Ghozali (2011) menyatakan bahwa uji interaksi merupakan aplikasi khusus regresi linear berganda dimana dalam persamaan regresinya mengandung unsur interakasi (perkalian dua atau lebih variabel independen) dan digunakan untuk menguji regresi. Model regresi yang dikembangkan untuk menguji hipotesis-hipotesis yang telah dirumuskan dalam penelitian ini adalah :

$$
\begin{aligned}
& \mathbf{P E}=\alpha+\beta_{1} \mathrm{ME}+\beta_{2} \mathrm{BE}+\beta_{3} \mathrm{KS}+\beta_{4} \mathrm{ME} * \mathrm{BE}+\beta_{5} \mathrm{ME} * \mathrm{KS}+\varepsilon \\
& \text { dimana: } \mathrm{PE}=\text { Perilaku Etis } \\
& \alpha=\text { konstanta } \\
& \beta_{1}-\beta_{6}=\text { koefisien regresi } \\
& \mathrm{ME}=\text { Muatan Etika } \\
& \mathrm{BE}=\text { Budaya Etis } \\
& \mathrm{KS}=\text { Kecerdasan Spiritual } \\
& \varepsilon=\text { residual }
\end{aligned}
$$

Persamaan di atas dihitung dengan menggunakan SPSS 24 dengan tingkat signifikansi $5 \%(\alpha=0,05)$. Untuk menganalisis hasil, maka dapat dilakukan dengan cara uji signifikansi individual (uji statistik t) dan uji signifikansi simultan (uji statistik F).

\section{HASIL DAN PEMBAHASAN}

\subsection{Gambaran Umum Responden}

Berdasarkan hasil distribusi kuesioner yang telah dilakukan dalam penelitian ini, maka berikut adalah tabulasi deskripsi responden. Deskripsi ini merupakan gambaran umum responden yang berpartisipasi dalam penelitian. Berdasarkan tabel 1 di bawah, maka dapat diuraikan bahwa responden penelitian ini $17,4 \%$ berjenis kelamin laki-laki dan $82,6 \%$ perempuan. Responden sebanyak $60,1 \%$ berumur antara $17-20$ tahun dan 39,9\% berumur lebih dari 20 tahun. Mayoritas responden penelitian berada di semester 4-6. $54 \%$ responden berindeks prestasi lebih dari 3 dan sisanya kurang dari 3. 
Tabel 1. Deskripsi Umum Responden Penelitian

\begin{tabular}{|c|c|c|}
\hline & Jumlah & $\%$ \\
\hline \multicolumn{3}{|l|}{ Jenis Kelamin: } \\
\hline$\checkmark \quad$ Laki-laki & 50 & 17,4 \\
\hline$\checkmark \quad$ Perempuan & 238 & 82,6 \\
\hline \multicolumn{3}{|l|}{ Umur: } \\
\hline$\checkmark \quad 17-20$ & 173 & 60,1 \\
\hline$\checkmark \quad 21-25$ & 113 & 39,2 \\
\hline$\checkmark \quad 26-30$ & 2 & 0,7 \\
\hline \multicolumn{3}{|l|}{ Semester: } \\
\hline$\checkmark \quad 4$ & 171 & 0,59 \\
\hline $5-6$ & 115 & 0,40 \\
\hline$\checkmark>6$ & 2 & 0,01 \\
\hline \multicolumn{3}{|l|}{ IPK } \\
\hline$\checkmark \leq 2,5$ & 16 & 0,06 \\
\hline$\checkmark \quad 2,51-2,75$ & 31 & 0,11 \\
\hline$\checkmark \quad 2,76-3$ & 85 & 0,29 \\
\hline$\checkmark>3$ & 156 & 0,54 \\
\hline
\end{tabular}

Sumber: Hasil Olahan Peneliti (2017)

\subsection{Response Rate Kuesioner}

Dalam tabel 2 dapat dilihat bahwa jumlah kuesioner yang disebarkan adalah sebanyak 368 kuesioner dengan jumlah item pernyataan atau pertanyaan sebanyak 42 butir. Dari 368 kuesioner yang disebarkan sebesar $84 \%$ atau sebanyak 310 kuesioner yang kembali dan hanya $78 \%$ (288 kuesioner) yang dapat diolah. Berikut adalah hasil tabulasi distribusi kuesioner yang dilakukan dalam penelitian ini:

Tabel 2. Tabulasi Distribusi Kuesioner

\begin{tabular}{lcc}
\hline & Jumlah & $\mathbf{\%}$ \\
\hline Kuesioner yang Didistribusikan & 368 & 100 \\
\hline Kuesioner yang Kembali & 310 & 84 \\
\hline Kuesioner yang Lengkap dan Dapat Diolah & 288 & 78 \\
\hline
\end{tabular}

Sumber: Hasil Olahan Peneliti (2017)

Berdasarkan hasil distribusi kuesioner sebagaimana nampak dalam tabel 2 di atas, menunjukkan bahwa tingkat response rate-nya sebanyak $84 \%$ dan yang terisi lengkap serta layak diolah sebanyak $78 \%$. Hal tersebut mengindikasikan tingkat pengembalian dan respon responden yang baik.

\subsection{Analisis Data}

\subsubsection{Statistik Deskriptif}

Dalam menganalisis data, tahap awal yang dilakukan adalah melakukan pengujian statitik deskriptif. Berikut ini adalah hasil statistik deskriptif :

Tabel 3. Hasil Statistik Deskriptif

\begin{tabular}{lccccc}
\hline \multicolumn{1}{c}{ Variabel } & N & Min & Maks & Std Deviasi & Mean \\
\hline $\begin{array}{l}\text { Muatan Etika } \\
\text { (ME) }\end{array}$ & 288 & 1,17 & 4,50 &, 49881 & 3,3385 \\
\hline Budaya Etis (BE) & 288 & 2,50 & 5,00 &, 39252 & 3,4384 \\
\hline $\begin{array}{l}\text { Kecerdasan } \\
\text { Spiritual (KS) }\end{array}$ & 288 & 2,88 & 4,71 &, 34628 & 3,8211 \\
\hline Perilaku Etis (PE) & 288 & 1,00 & 4,00 &, 58154 & 2,3547 \\
\hline
\end{tabular}

Sumber: Hasil Olahan Peneliti (2017) 
Berdasarkan tabel di atas, menunjukkan bahwa muatan etika mempunyai nilai minimum1,17, nilai maksimum 4,50, dan nilai rata-rata 3,3385. Hal tersebut menggambarkan bahwa pemberian muatan etika di AA YKPN Yogyakarta mempunyai rata-rata relatif tinggi. Standar deviasi sebesar 0,49881 menunjukkan bahwa berdasar hasil statistik deskriptif terjadi perbedaan pemberian muatan etika dengan nilai rataratanya.

Budaya etis mempunyai nilai minimum 2,50, nilai maksimum 5,0, dan nilai rata-rata 3,4384. Hal tersebut mendeskripsikan bahwa budaya etis yang dimiliki mahasiswa AA YKPN Yogyakarta mempunyai rata-rata tinggi. Deviasi standar sebesar 0,39252 menunjukkan bahwa berdasarkan hasil statistik deskriptif terjadi perbedaan budaya etis yang dimiliki mahasiswa terhadap nilai rata-ratanya.

Variabel kecerdasan spiritual mempunyai nilai minimum 2,88, nilai maksimum 4,71, dan nilai rata-rata sebesar 3,8211. Hal tersebut mengilustrasikan bahwa kecerdasan spiritual mahasiswa AA YKPN mempunyai rata-rata tinggi. Nilai deviasi standar kecerdasan spiritual senilai 0,34628 yang menunjukkan bahwa berdasarkan hasil statistik deskriptif terjadi perbedaan kecerdasarn spiritual mahasiswa AA YKPN Yogyakarta dengan nilai rata-ratanya sebesar 0,34628 .

Sedangkan perilaku etis mahasiswa AA YKPN Yogyakarta menunjukkan nilai mininum 1,00, nilai maksimum 4,00, dan nilai rata-rata 2,3547. Hal tersebut mengindikasikan bahwa perilaku etisnya mempunyai rata-rata relatif tinggi. Dan deviasi standar sebesar 0,58154 berdasarkan hasil statistik deskriptif menunjukkan terjadi perbedaan perilaku etis mahasiswa AA YKPN Yogyakarta dengan nilai rata-ratanya.

\subsubsection{Uji Kualitas Data}

\section{Hasil Uji Validitas dan Reliabilitas}

Hasil Uji Validitas menunjukkan bahwa semua pertanyaan dalam kuesioner yang sudah dibuat benar-benar dapat mengukur apa yang hendak diukur oleh peneliti karena seluruh item pertanyaan untuk perilaku etis mahasiswa memiliki nilai $r$ hitung $>r$ tabel yang berarti bahwa seluruh item pertanyaan untuk variabel perilaku etis dinyatakan valid.

Berdasarkan hasil uji validitas yang telah dilakukan dalam penelitian ini menunjukkan bahwa item pernyataan yang mempunyai nilai corrected item-total correlation ( $t$-hitung) $>0,10469$ ( $t$-table) maka dinyatakan valid. Item pernyataan atau pertanyaan mempunyai $\mathrm{r}$ hitung $<0,10469$ maka akan dihapus dan tidak diikutsertakan dalam pengujian selanjutnya.

Sedangkan hasil pengujian reliabilitas menggunakan cronbach alpha per variabel nampak sebagaimana tabel berikut ini. Dan hasil menujukkan bahwa semua item pernyataan atau pernyataan dinilai reliabel karena nilai Cronbach Alpha $>0.60$ atas semua pernyataan atau pertanyaan dari variabel dependen dan independen teruji reliabilitasnya.Secara rinci nampak dalam tabel berikut:

Tabel 4. Hasil Pengujian Reliabilitas

\begin{tabular}{ccl}
\hline Variabel & Cronbach Alpha & \\
\hline $\mathrm{ME}$ & 0,653 & reliabel \\
\hline $\mathrm{BE}$ & 0,791 & reliabel \\
\hline $\mathrm{KS}$ & 0,761 & reliabel \\
\hline $\mathrm{PE}$ & 0,705 & reliabel \\
\hline
\end{tabular}

Sumber: Hasil Olahan SPSS 24 (2017)

\subsubsection{Uji Asumsi Klasik}

\section{a. Uji Normalitas Regresi}

Pengujian normalitas dalam penelitian ini dilakukan dengan menggunakan P-Plot. Dan hasil pengujian normalitas nampak sebagaimana gambar berikut ini: 


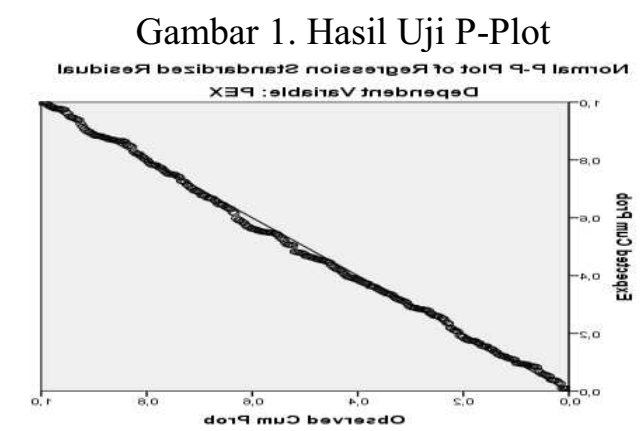

Sumber: Hasil Olahan SPSS 24 (2017)

Berdasarkan gambar di atas, maka dapat disimpulkan bahwa data berdistribusi normal. Hal tersebut nampak pada titik-titik data berada dekat dengan garis diagonal.

\section{b. Uji Multikolinearitas}

Salah satu cara untuk mendeteksi adanya multikolinieritas yaitu berdasarkan VIF (Variance Inflation Factor) dan besaran tolenrance. Adapun hasil uji multikolinieritas menunjukkan hasil bahwa VIF untuk variabel independen yang berada dibawah 10 dan nilai tolerance variabel independen yang besaran tolerance $>0,1$, sehingga dapat disimpulkan bahwa tidak terdapat multikolinearitas antar variabel bebas.Tabel berikut menunjukkan hasil uji multikolinieritas dalam penelitian ini yang menunjukkan tidak terjadi multikolinieritas:

Tabel 5. Hasil Pengujian Multikolinieritas

\begin{tabular}{llcc}
\hline & & \multicolumn{2}{c}{ Collinearity Statistics } \\
Model & & Tolerance & VIF \\
\hline 1 & ME &, 922 & 1,085 \\
\cline { 2 - 4 } & KS &, 725 & 1,380 \\
\cline { 2 - 4 } & BE &, 751 & 1,332 \\
\hline
\end{tabular}

a. Dependent Variable: PE

Sumber: Hasil Olahan SPSS 24 (2017)

\section{c. Uji Heteroskedastisitas}

Uji heterokedastisitas dalam penelitian ini menggunakan uji scatterplot. Dan hasil uji heterokedastisitas yang dilakukan dalam penelitian ini sebagaimana nampak dalam gambar berikut ini dan menunjukkan data tidak mengalami heterokedastisitas:

Gambar 2. Hasil Uji Heterokedastisitas

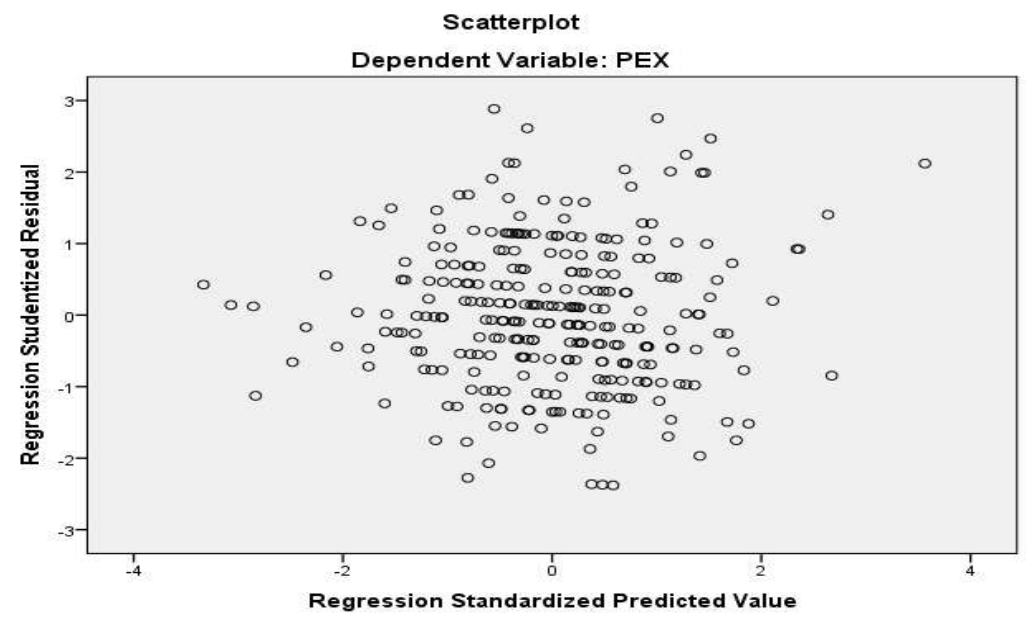

Sumber: Hasil Olahan SPSS 24 (2017) 
Hasil uji di atas menunjukkan bahwa data tidak mengalami heterokedastisitas karena data menyebar dan tidak ada pola yang jelas.Titik-titik data menyebar diatas dan

\subsubsection{Uji Hipotesis}

dibawah angka 0 pada sumbu Y (Ghozali, 2011:105).

Dalam penelitian ini pengujian hipotesis dilakukan dengan Moderated Regression Analysis (MRA).

Adapun hasil yang diperoleh sebagaimana akan diuraikan berikut ini:

\section{a. Uji signifikansi parameter individual (Uji statistik t)}

Uji dilakukan untuk mengetahui seberapa jauh satu variabel independen secara individual mampu menjelaskan variabel dependen. Apabila tingkat signifikansi $<0,05 \mathrm{Ha}$ diterima dan Ha ditolak apabila tingkat signifikansi $>0,05$. Berikut tabulasi hasil uji t:

Tabel 6. Hasil Uji t

\begin{tabular}{|c|c|c|c|c|c|c|}
\hline & \multirow{2}{*}{ Model } & \multicolumn{2}{|c|}{ Unstandardized Coefficients } & $\begin{array}{l}\text { Standardized } \\
\text { Coefficients }\end{array}$ & \multirow[t]{2}{*}{$\mathrm{t}$} & \multirow[t]{2}{*}{ Sig. } \\
\hline & & B & Std. Error & Beta & & \\
\hline \multirow[t]{6}{*}{1} & (Constant) & 2,348 &, 035 & & 66,163 &, 000 \\
\hline & $\mathrm{ME}$ &, 007 &, 006 &, 006 & 1,079 & ,281 \\
\hline & KS &,- 472 &, 030 &,- 281 & $-15,725$ &, 000 \\
\hline & $\mathrm{BE}$ &,- 154 &, 032 &,- 104 & $-4,803$ & 000 \\
\hline & KS*PE & 200 & ,012 &, 818 & 17,251 & 000 \\
\hline & $\mathrm{BE} * \mathrm{PE}$ &, 064 & 013 &, 256 & 5,102 &, 000 \\
\hline
\end{tabular}

a. Dependent Variable: PE

Sumber: Hasil Olahan SPSS 24 (2017)

Berdasarkan tabel di atas, maka dapat disimpulkan bahwa muatan etika tidak mempengaruhi perilaku etis mahasiswa. Hal tersebut ditunjukkan dari nilai signifikansi yang lebih besar dari 0.05 yaitu 0,281 .dan nilai t 1,079 . Dengan demikian H1 ditolak.

Interaksi kecerdasan spiritual terhadap hubungan antara muatan etika dengan perilaku etis menunjukkan nilai signifikansi 0,00 yang lebih kecil dari 0,05 dengan nilai $\mathrm{t}$ 17,251. Hal tersebut mengindikasikan bahwa kecerdasan spiritual memperkuat hubungan antara muatan etika dengan perilaku etis mahasiswa.

Sedangkan interaksi budaya etis terhadap hubungan antara muatan etika dengan perilaku etis menunjukkan nilai signifikansi 0,00 yang lebih kecil dari 0,05 dengan nilai t 5,102. Hal tersebut mengindikasikan bahwa budaya etis memperkuat hubungan antara muatan etika dengan perilaku etis mahasiswa.

b. Uji signifikansi simultan (Uji statistik f)

Uji statistik F pada dasarnya menunjukkan apakah semua variabel bebas yang dimasukkan dalam model mempunyai pengaruh secara simultan terhadap variabel terikat. Kriteria Uji: jika nilai signifikansinya $<0,05$, maka $\mathrm{H}_{0}$ ditolak, Ha diterima. Demikian pula sebaliknya.

Tabel 7. Hasil Uji F

\begin{tabular}{llr|r|r|c|c}
\hline \multicolumn{1}{l}{ Model } & $\begin{array}{c}\text { Sum of } \\
\text { Squares }\end{array}$ & df & Mean Square & F & \multicolumn{1}{c}{ Sig. } \\
\hline 1 & Regression & 96,382 & 5 & 19,276 & 8019,466 &, $000^{6}$ \\
\cline { 2 - 7 } & Residual &, 678 & 282 &, 002 & & \\
\cline { 2 - 5 } & 97,059 & 287 & & & \\
\hline
\end{tabular}

a. Dependent Variable: PE

b. Predictors: (Constant), BE*ME, ME, KS, BE, KS*ME

Sumber: Hasil Olahan SPSS 24 (2017) 
Berdasarkan tabel di atas, maka dapat disimpulkan bahwa muatan etika, kecerdasan spiritual, budaya etis, $\mathrm{KS}^{*} \mathrm{ME}, \mathrm{BE}^{*} \mathrm{ME}$ secara simultan berpengaruh pada perilaku etis mahasiswa. Hal tersebut ditunjukkan dari nilai signifikansi yang lebih kecil dari 0.05 yaitu 0,00 .dan nilai t 8019,466 .

c. Koefisien determinasi $\left(\mathbf{R}^{2}\right)$

Koefisein determinasi $\left(\mathrm{R}^{2}\right)$ dapat dilihat pada nilai Adjusted $R$ Square yang menunjukkan seberapa besar variabel independent dapat menjelaskan variabel dependen. Nilai koefisien determinasi adalah $0 \leq R^{2} \leq 1$.

Hasil pengujian dalam penelitian ini menunjukkan nilai adjusted $R$ Square sebesar 0,993. Artinya bahwa variabel muatan etika, budaya etis, kecerdasan spiritual mampu menjelaskan perilaku etis mahasiswa sebesar $99,3 \%$ dan sisanya dijelaskan oleh variabel lain.

Tabel 8. Hasil Uji Koefisien Determinasi

\begin{tabular}{rr|r|rrr}
\hline Model & $\mathrm{R}$ & R Square & \multicolumn{1}{c}{$\begin{array}{c}\text { Adjusted R } \\
\text { Square }\end{array}$} & $\begin{array}{c}\text { Std. Error of the } \\
\text { Estimate }\end{array}$ \\
\hline 1 &, $997^{\mathrm{a}}$ &, 993 &, 993 &, 04903 \\
\hline
\end{tabular}

a. Predictors: (Constant), BE*ME, ME, KS, BE, KS*ME

Sumber: Hasil Olahan SPSS 24 (2017)

\subsubsection{Interpretasi Hasil Pengolahan Data Dan Pembahasan}

Pengujian Hipotesis 1 menunjukkan bahwa H1 ditolak yang berarti bahwa muatan etika tidak memengaruhi perilaku etis mahasiswa. Hal tersebut sejalan dengan hasil penelitian Agustina dan Susilawati (2012), namun tidak konsisten dengan penelitian Sari (2013), Sapariyah et al. (2016), Yunika (2014), dan Utami dan Indriawati (2006). Kondisi di atas dimungkinkan terjadi karena pemberian muatan etika dalam proses pendidikan dan pembelajaran belum dilaksanakan secara optimal termasuk kekurangmampuan tenaga pendidik dalam mengidentifikasi dan mengkorelasikan antara muatan-muatan etika dalam tiap topik bahasan dalam pelajaran akuntansi.

Pengujian Hipotesis 2 menunjukkan bahwa $\mathrm{H} 2$ diterima yang berarti bahwa budaya etis mampu menguatkan hubungan antara muatan etika dengan perilaku etis mahasiswa. Hal tersebut ditunjukkan dari nilai signifikansinya yang lebih kecil dari 0,05 . Kondisi tersebut mengindikasikan bahwa budaya etis baik yang tercipta ternyata memberikan pengaruh yang besar terhadap perilaku etis mahasiswa akuntansi. Dengan demikian upaya pendidikan vokasi akuntansi dalam meningkatkan perilaku etis mahasiswanya, selain memberikan muatan etika dalam pengajaran akuntansi juga bekerja sama dengan orang tua dalam penanaman nilai-nilai yang baik.

Pengujian Hipotesis 3 menunjukkan bahwa H3 diterima yang berarti bahwa kecerdasan spiritual mampu menguatkan hubungan antara muatan etika dengan perilaku etis mahasiswa. Hal tersebut ditunjukkan dari nilai signifikansinya yang lebih kecil dari 0,05. Dengan demikian dapat diinterpretasikan bahwa dalam rangka meningkatkan atau memperbaiki perilaku etis mahasiswa, maka selain memberikan muatan etika dalam pengajaran akuntansi di pendidikan vokasi juga menggalakkan aktivitas yang mengasah kecerdasan spiritual mahasiswa.

\section{PENUTUP}

\subsection{Simpulan}

Dari hasil penelitian yang telah dilakukan, maka dapat disimpulkan bahwa muatan etika secara parsial tidak mempengaruhi perilaku etis mahasuswa. Interaksi budaya etis dan kecerdasan spiritual dapat menguatkan hubungan antara muatan etika dengan perilaku etis mahasiswa. 


\subsection{Keterbatasan.}

Penelitian ini memiliki beberapa keterbatasan antara lain bahwa: (1) penelitian ini menggunakan responden yang kurang beragam karena hanya dari 1 perguruan tinggi di Yogyakarta dan penentuannyapun kurang selektif, (2) hasil uji reliabilitas per item dalam penelitian ini ada yang menunjukkan ketidakreliabelan $(<0,06)$, namun jika direduksi menyebabkan semakin tidak reliabel untuk item yang lain,walaupun secara total per variabel semuanya reliabel, (3) kekurangjelian peneliti dalam menganalisis uji normalitas datanya yang hanya menggunakan Scatter Plot, (4) instrumen untuk mengukur budaya etis dimodifikasi dengan pertimbangan terbatas, dari budaya etis level organisasi menjadi budaya etis level keluarga karena agar responden nampak lebih beragam karakteristiknya, (5) teknik pengumpulan data hanya dilakukan melalui pengisian kuesioner saja, (6) keterbatasan waktu yang diberikan kepada responden saat pengisian kuesioner (10-15 menit).

\subsection{Saran dan Implikasi Praktis}

Adapun saran yang dapat diberikan meliputi: (1) memperluas target responden penelitian secara lebih selektif, (2) kekurangreliabelan yang terjadi pada variabel muatan etika dapat diatasi dengan menelaah secara lebih teliti intrumen yang dipakai dan pada saat didistribusikan perlu adanya pendekatan lebih personal sehingga memungkinkan terjadinya komunikasi dan mereduksi kekurangpemahaman responden atas item yang dinyatakan atau ditanyakan, (3) Ada baiknya peneliti selanjutnya mengkaji uji normalitas secara lebih teliti dan tidak hanya menggunakan Scatter Plot atau Kolmogorof Smirnov saja, (4) Sebaiknya instrumen budaya etis ditelaah lebih jauh ketepatan penggunaannya, (5) Ada baiknya, teknik pengumpulan datanya menggunakan kuesioner secara personal dengan menambahkan ada proses diskusi dan wawancara, (6) Sebaiknya responden diberikan waktu yang cukup dan menggunakan pendekatan personal (face to face) agar kualitas isian dan response rate-nya tinggi.

Implikasi Praktis bagi pendidikan akuntansi adalah urgent-nya pemberian muatan etika pada mahasiswa sebagai generasi penerus bangsa dan media perbaikan citra profesi yang terpurukserta krisis multidimensi sehingga penekanan pelaksanaan pendidikan sebaiknya tidak hanya menekankan pada nilai akademis dan kecerdasan otak saja, namun juga mendidik tentang integritas, kejujuran, komitmen dan keadilan yang terabaikan.

\section{DAFTAR PUSTAKA}

Agustina, L., dan Susilawati, C. D. K. 2012. Dampak Muatan Etika dalam Pengajaran Akuntansi Keuangan dan Audit terhadap Persepsi Etika Mahasiswa yang dimoderasi oleh Kecerdasan Kognisi dan Keverdasan Emosional: Studi Eksperimen Semu. Jurnal Akuntansi 4 (1): 22-32.

Ameen, E. C., Guffrey, D. M., dan McMillan, J. J. 1996. Gender Differences in Determining the Ethical Sensitivity of Future Accounting Professional. Journal of Business Ethics (15) 5: 591-597.

Azwar, S. 2004. Pengantar Psikologi Intelegensi. Cetakan Keempat. Yogyakarta: Pustaka Pelajar.

Becker, D. A., dan Ulstad, I. 2007. Gender Differences in Student Ethics: Are Female Really More Ethical? Plagiary: Cross-Disciplinary Studies in Palgiarsm, Fabrication, and Falsification: 77-91.

Brenner, V.C., Watkins, A. L., dan Flynn, P. 2012. Accounting Student Views on Ethics. Journal of Accounting and Finance 12 (5): 110-117. 
Chin, W.W. 1995. Partial Least Squareis to LISREL as Principal Componwnta Analysis is to common Factor Analysis. Technology Studies (2): 315-319.

Cohen, J. R., Pant, L. W., dan Sharp, D. J. 1998. The Effect of Gender and Academic Disipline Diversity on the Ethical Evaluation, Ethical Intentions and Ethical Orientation of Potential Public Accounting Recruits. Accounting Horizon (12)3: 250-270.

Damayanti, P. D. A., dan Juliarsa, G. 2016. Pengaruh Idealisme, Relativisme. Pengetahuan, Gender, dan Umur pada perilaku Tidak Etis Akuntan, Jurnal Akuntansi 15 (1): 1-16

Damayanti, P. D. A., dan Juliarsa, G. 2016. Budaya Etis Organisasi sebagai Variabel Pemoderasi Pengaruh Orientasi Etis pada Pertimbangan Etis Auditor, Jurnal Akuntansi 17 (2): 1226-1253

Dewi, J.S., Widianingsih, L. P., dan Upa, V. A. 2014. Analisis Perbedaan Gender terhadap Perilaku Etis, Orientasi Etis dan Profesionalisme pada Auditor KAP di Surabaya. Jurnal GEMA AKTUALITA 3 (1):

Endro, G. 1999. Redefinisi Bisnis: Suatu penggalian Etika Keutamaan Aristoteles. Jakarta: PT. Pustaka Binaman Pressindo.

Fakih. 2001. Analisis Gender dan Transformasi Sosial. Yogyakarta: Pustaka Pelajar.

Falah, S. 2006. Pengaruh Budaya Etis Organisasi dan Orientasi Etika terhadap Sensitivitas Etika. Tesis Magister Sains Akuntansi Universitas Diponegoro Semarang.

Fauzi, A. 2001. Pengaruh Perbedaan Faktor-faktor Individual terhadap Perilaku Etis Mahasiswa Akuntansi. Tesis. Program Pascasarjana Universitas Gadjah Mada, Yogyakarta.

Finn, D. W., Munter, P., dan McCaslin, T. E. 1994. Ethical Perceptions of CPAs. Managerial Auditing Journal.9 (1): 23-28.

Fudyartanta, K. 2004. Tes Bakat dan Penskalaan Kecerdasan . Yogyakarta: Pustaka Pelajar.

Goleman, D. 2005. Kecerdasan Emosi untuk Mencapai Puncak Prestasi. Edisi Keenam. Jakarta: PT Gramedia Putaka Utama.

Ghozali, I. 2011. Aplikasi Analisis Multivariate dengan Program IBM SPSS19, Edisi 5. Badan Penerbit Universitas Diponegoro. Semarang.

Hair et al. 2006. Multivariate Data Analysis. $6^{\text {th }}$ Edition. New Jersey: Pearson Education.

Hastuti, S. 2007. Perilaku Etis Mahasiswa dan Dosen Ditinjau dari faktor Individual Gender dan Locus of Control. Jurnal Riset Ekonomi dan Bisnis 7 (7) : 58-73.

Huck, S. W., dan Cormier, W. H. 1996. Reading Statistics and Research. Second Edition. New York: Harper Collins Publisher Inc. 
Hunt, S.D., V. R. Wood dan L.B. Chonko. 1989. Corporate Ethical Value and Organizational Commitment in Marketing. Journal of Marketing 53 Juli: 79-90.

Husemen, R. C., Hatfield, J. D., dan Miles, E. W. (1987). A New Perspective on Equity Theory: The Equity Sensitivity Construct. Academy of Management Review, Vol.12: 222-234.

Jones, G. E., dan Kavanagh, M. J. 1996. An Experimental Examination of the Effects of Individual and Situasional Factors on Unethical Behavior Intentions in the Workplace. Journal of Business Ethics, Vol. 15, No.5: 511-523.

Keraf, A. S. 1998. Etika Bisnis: membangun Citra Bisnis sebagai Profesi Luhur. Yogyakarta: Penerbit Kanisius.

Khomsyah dan Indriantoro, N. 1998. Pengaruh Orientasi Etika terhadap KOmitmen dan Sensitivitas Etika Auditor Pemerintah di DKI Jakarta. Jurnal Riset Akuntansi Indonesia 1 (1): 13-28.

Lisda, A. 2009. Pengaruh Kemampuan Intelektual, Kecerdasan Emosional, dan Kecerdasan Spiritual terhadap Perilaku Etis Auditor serta Dampaknya pada Kinerja (studi Empiris pada KAP di Jakarta). Universitas Islam Negeri Syarif Hidayatullah.

Lucyanda, J. dan G. Endro. 2012. Faktor-Faktor yang Mempengaruhi Perilaku Etis Mahasiswa Akuntansi Universitas Bakrie. Media Riset Akuntansi. Vol. 2 (2): 113142.

Malone, F. L. 2006. The Ethical Attitudes os Accounting Students. Journal of The American Academy of Business 8(1): 142-146.

Martina, M.B., Werastuti, D.M., dan Sujana, E. 2015. Pengaruh Budaya Etis Organisasi, Orientasi Etika, Pengalaman, dan Profesionalisme terhadap Sensitivitas Etika Kegiatan Audit yang dilaksanakan Inspektorat Pemerintah Kabupaten Buleleng. Ejournal S1 Akuntansi Universitas Pendidikan Ganesha, Vol. 3, No. 1:1-11.

Maryani, T., dan Ludigdo, U. 2001. Survey atas Faktor-faktor yang Mempengaruhi Sikap dan Perilaku Etis Akuntan. Jurnal TEMA 2 (1): 49-62.

Mautz, R. K., dan Sharaf, H. A. 1993. The Philosofy of Auditing. USA: American Accounting Association.

Nugrahaningsih, P. 2005. Analisis Perbedaan Perilaku Etis Auditor di Kantor Akuntan Publik dalam Etika Profesi (Studi terhadap Peran Faktor-faktor individual: Locus of Control, Lama Pengalaman Kerja, Gender, dan Equity Sensitivity). Proceeding Simposium Nasional Akuntansi VIII Solo: 617-630.

Rahim, A., dan Rahman, A. 2003. Ethics in Accounting Education: Contribution of The Islamic Principle of Maelaiah. IIUM Journal of Economics dan Management 11(1): $1-16$.

Ramly, Z., Chai, L. T., dan Lung, C. K. 2008. Religiosity as a Predictor of Consumer Ethical Behavior: Some Evidence from Young Consumers from Malaysia. Journal of Business Systems, Governance and Ethics 3(4): 43-56. 
Reiss, M. C., dan Mitra, K. 1998. The Effects of Individual Difference Factors on the Acceptability of Ethical and Unethical Workplace Behaviors. Journal of Business Ethics, Vol.17, No.12: 1581-1593.

Robbins, S. P., dan Judge, T. A. 2011. Organizational Behavior.13 ${ }^{\text {th }}$ Edition. US: PrenticeHall

Sapariyah, R. A., Setyorini, Y., dan Dharma, A. B. (2016). Pengaruh Muatan Etika dalam Pengajaran Akuntansi Keuangan, Kecerdasan Intelektual, Kecerdasan Emosional, dan Kecerdasan Spiritual terhadap Sikap Etis Mahasiswa Akuntansi. Jurnal Paradigma 13 (2): 1-15.

Sari, L. P. 2013. Pengaruh Muatan Pendidikan Etika dalam Pendidikan Akuntansi Terhadap Persepsi Etika Mahasiswa (Studi Pada Jurusan Akuntansi fakultas Ekonomi dan Bisnis Universitas Brawijaya Malang Angkatan 2009). Jurnal Ilmiah Mahasiswa Fakultas Ekonomi dan Bisnis Universitas Brawijaya

Sari, R. S. N., Zuhdi, R., dan Herawati, N. 2012. Tafsir Perilaku Etis Menurut Mahasiswa Akuntansi Berbasis Gender. Jurnal Akuntansi Multiparadigm 3(1,): 125-133

Syafruddin, M. 2005. Kasus Mulyana dalam Perspektif Etika. Suara Merdeka April: 6

Tikollah, M. R., Triyuwono, I., dan Ludigdo, U. 2006 Pengaruh Kecerdasan Intelektual, Kecerdasan Emosional, dan Kecerdasan Spiritual Terhadap Sikap Etis Mahasiswa Akuntansi (Studi pada Perguruan Tinggi Negeri di Kota Makasar Provinsi Sulawesi Selatan). Proceeding Simposium Nasional Akuntansi IX Padang: 1-25.

Triani, A. A. 2011. Pengaruh Gender dan Muatan Etika dalam Pengajaran Akuntansi Keuangan pada Persepsi Etika Mahasiswa. Ultima Accounting 2(1): 14-32

Ustadi, N. H., dan Utami, R. D. 2005. Analisis Perbedaan Faktor-faktor Individual Terhadap Persepsi Perilaku Etis Mahasiswa. Jurnal Akuntansi dan Auditing 1 (2): 162-180.

Utami, W., dan Indriawati, F. 2006. Muatan Etika dalam Pengajaran Akuntansi Keuangan dan Dampaknya terhadap Persepsi Etika Mahasiswa: Studi Eksperimen Semu. Simposium Nasional Akuntansi 9 Padang, 23-26 Agustus.

Yunika, W. 2014. Pengaruh Muatan Etika dalam Pengajaran Akuntansi Keuangan dan Prestasi Mahasiswa terhadap Persepsi Etika Mahasiswa. Prosiding Seminar Nasional dan Call for Papers UNIBA: 115-120.

Zohar, D., dan Marshall, I. 2001. SQ: Memanfaatkan Kecerdasan Spiritual dalam Berpikir Integralistik dan Holistik untuk Memaknai Kehidupan. Diterjemahkan oleh Rahmi Astuti, Ahmad Najib Burhani dan Ahmad Baiquni. Bandung: Mizan. 


\section{Lampiran Kuesioner}

\section{DAFTAR PERTANYAAN}

\section{Karakteristik Responden}

1. Jenis Kelamin : Laki-laki erempuan

2. Umur : 7-20 tahun -25 tahun 30 tahun

3. Semester

4. Pernah Menempuh Mata Kuliah Pengauditan dan Etika Bisnis Profesi ?
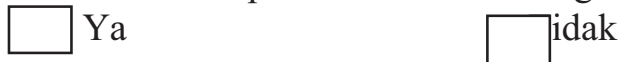

5. IPK

\section{Petunjuk:}

Anda diminta memberikan pendapat terkait isu-isu etika

Pilihlah alternatif jawaban yang menurut anda tepat dengan memberikan tanda silang $(\mathrm{X})$

Semua item pertanyaan/pernyataan diukur menggunakan 5 skala likert:
1 = Sangat Tidak Setuju
2 = Tidak Setuju
$3=$ Netral
$4=$ Setuju
5 = Sangat Setuju 


\begin{tabular}{|c|c|c|c|c|c|c|}
\hline NO & URAIAN & 1 & 2 & 3 & 4 & 5 \\
\hline 1 & $\begin{array}{l}\text { Saya sering mendapatkan tugas refleksi batin spiritual dari } \\
\text { dosen }\end{array}$ & & & & & \\
\hline 2 & Saya sering diberi kasus-kasus etika dalam mata kuliah & & & & & \\
\hline 3 & $\begin{array}{l}\text { Saya sering diberi tugas dosen membaca isu-isu etika di } \\
\text { media massa dan memaknainya }\end{array}$ & & & & & \\
\hline 4 & Saya sering berdiskusi kasus-kasus etika dengan dosen & & & & & \\
\hline 5 & $\begin{array}{l}\text { Dosen berusaha mengajarkan hal-hal terkait etika untuk mata } \\
\text { kuliah yang tidak berhubungan dengan etika secara spesifik }\end{array}$ & & & & & \\
\hline 6 & $\begin{array}{l}\text { Dosen secara kreatif memancing pemikiran dan daya kritis } \\
\text { saya terkait kasus etika }\end{array}$ & & & & & \\
\hline 7 & Saya fleksibel dan mampu beradaptasi & & & & & \\
\hline 8 & Saya bersikap spontan dalam menghadapi situasi baru & & & & & \\
\hline 9 & Saya memiliki tingkat kesadaran diri yang tinggi & & & & & \\
\hline 10 & $\begin{array}{l}\text { Saya mampu memahami dan menanggung penderitaan fisik } \\
\text { dan psikologis }\end{array}$ & & & & & \\
\hline 11 & $\begin{array}{l}\text { Saya mengarahkan hidup saya untuk menjalankan perintah- } \\
\text { Nya dan menjauhi larangan-Nya }\end{array}$ & & & & & \\
\hline 12 & $\begin{array}{l}\text { Saya memandang bahwa setiap agama mempunyai kesamaan } \\
\text { nilai sebagai bagian dari kebenaran }\end{array}$ & & & & & \\
\hline 13 & Saya mencari makna dan tujuan hidup ini & & & & & \\
\hline 14 & Saya memandang baik-buruk atau benar-salah adalah relatif & & & & & \\
\hline 15 & $\begin{array}{l}\text { Saya mempercayai bahwa Tuhan akan memberikan apa yang } \\
\text { saya butuhkan }\end{array}$ & & & & & \\
\hline 16 & $\begin{array}{l}\text { Saya telah memperbaiki diri dari keyakinan-keyakinan keliru } \\
\text { yang diperlajari dari keluarga atau kebudayaan saya }\end{array}$ & & & & & \\
\hline 17 & Saya dapat mengetahui kebenaran tanpa perlu diberitahu & & & & & \\
\hline 18 & $\begin{array}{|lllll|}\begin{array}{l}\text { Orang-orang seringkali } \\
\text { kekanak-kanakan }\end{array} & \text { mengomentari } & \text { sifat } & \text { saya } & \text { yang } \\
\end{array}$ & & & & & \\
\hline 19 & $\begin{array}{l}\text { Saya memaknai kejadian-kejadian yang terjadi dalam konteks } \\
\text { yang luas }\end{array}$ & & & & & \\
\hline 20 & Saya menjalani hidup dengan nikmat dan optimisme & & & & & \\
\hline 21 & $\begin{array}{l}\text { Saya menangkap nilai-nilai spiritual yang lebih tinggi dalam } \\
\text { diri orang lain dan menerapkannya pada diri saya }\end{array}$ & & & & & \\
\hline 22 & $\begin{array}{l}\text { Saya mengorban kebutuhan ego personal diri untuk } \\
\text { memberikan yang terbaik bagi orang lain, bahkan untuk orang } \\
\text { asing sekalipun }\end{array}$ & & & & & \\
\hline 23 & $\begin{array}{l}\text { Dalam keluarga, saya didorong bertanggungjawab penuh } \\
\text { terhadap tindakannya }\end{array}$ & & & & & \\
\hline 24 & Orang tua saya menunjukkan standar etika yang tinggi & & & & & \\
\hline 25 & Keluarga saya sering terlibat dalam perilaku tidak etis & & & & & \\
\hline
\end{tabular}




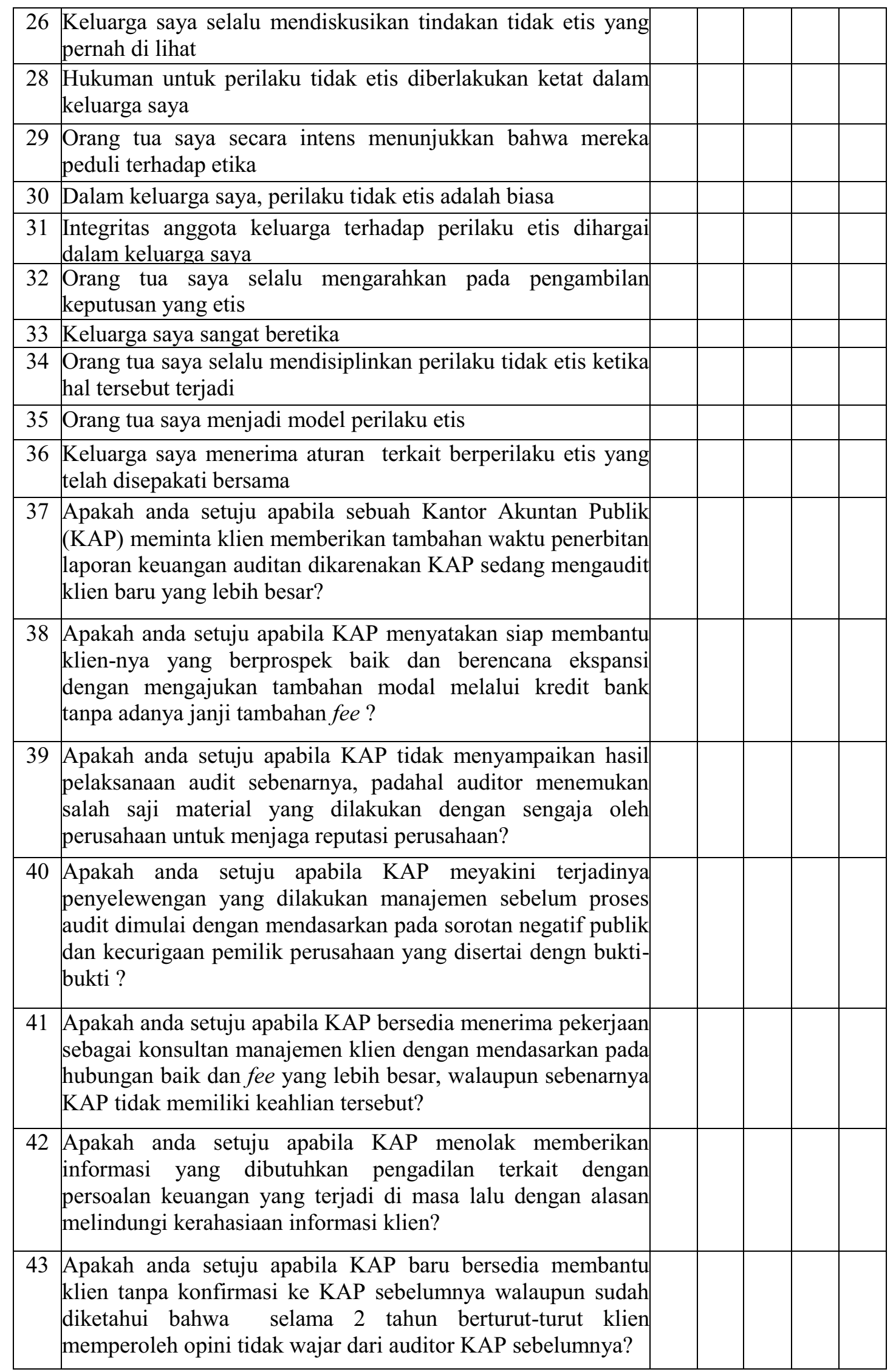

